\title{
O poder constituinte e a justiça de transição no Brasil
}

\author{
The CONSTITUENT POWER AND TRANSITIONAL \\ JUSTICE IN BRAZIL \\ * Bruno Meneses Lorenzetto \\ ** Katya Kozicki
}

* Professor de Direito da Pontifícia Universidade Católica do Paraná. Visitng Scholar na Columbia Law School, Columbia University, New York (20132014). Doutor em Direito pela UFPR na área de Direitos Humanos e Democracia (2010-2014). Mestre em Direito pela UFPR na área do Direito das Relações Sociais (20082010). Graduado em Direito pela Pontifícia Universidade Católica do Paraná (20032008). Bolsista pela CAPES durante o Mestrado na UFPR. Desenvolve suas pesquisas na área de Direito, com ênfase em Teoria do Direito e Direito Constitucional. E-mail: bruno lorenzetto@yahoo.com.br

**Doutorado em Direito, Política e Sociedade pela Universidade Federal de Santa Catarina. Visiting Researcher Associate no Centre for the Study of Democracy, University of Westminster, Londres, 1998-1999. Professora titular da Pontifícia Universidade Católica do Paraná e professora associada da Universidade Federal do Paraná. E-mail: kkozicki@ uol.com.br
Resumo: O presente artigo procura refletir sobre duas grandes questões teóricas fundamentais na formação do Estado moderno que estão entrelaçadas. A produção de constituições novas, a mudança da regra de reconhecimento que permite a entrada das normas no ordenamento jurídico, bem como a questão atinente à justiça de transição, as ações políticas concretas que devem ser tomadas em relação a regimes políticos anteriores e seus respectivos atores políticos.

Palavras-chave: Poder constituinte. Justiça de transição. Democracia.

Abstract: This article discusses two major fundamental theoretical issues in the formation of the modern state that are intertwined. The production of new constitutions, the change of the rule of recognition that allows the entry of statutes in the legal system as well as the question regarding the transitional justice, concrete policy actions that have to be taken in relation to previous political regimes and their political actors.

Keywords: Constituent power. Transitional justice. Democracy. 


\section{INTRODUÇÃO}

A passagem de um sistema normativo antigo para um novo sistema normativo demanda, costumeiramente, regras que promovam as devidas adaptações em relação à ordem institucional. Com a mudança da Norma Fundamental o restante do sistema deverá ser adequado perante este novo critério de validade normativo. Contudo, seria contra intuitivo a realização do teste de constitucionalidade de todo o extenso rol de normas infraconstitucionais previamente estabelecidas. Por esta razão, via de regra, formula-se o pressuposto de que as normas foram recepcionadas e são válidas no novo ordenamento - até que sua constitucionalidade venha a ser questionada ou uma nova disposição legislativa venha a ser formulada em seu lugar. ${ }^{1}$

Virtualmente, toda a legislação infraconstitucional é recepcionada automaticamente, porém, a possibilidade do questionamento da constitucionalidade desta legislação, do seu ajuste ao novo ordenamento jurídico, continua latente, podendo eventualmente vir a ser provocado mesmo após anos de silêncio ou omissão (em muitos casos, intencionais, pactuados, fundados em escolhas ideológicas).

art. $1^{\circ} \mathrm{A}$ argüição prevista no $\S 1^{\circ}$ o do art. 102 da Constituição Federal será proposta perante o Supremo Tribunal Federal, e terá por objeto evitar ou reparar lesão a preceito fundamental, resultante de ato do Poder Público.Parágrafo único. Caberá também argüição de descumprimento de preceito fundamental:I - quando for relevante o fundamento da controvérsia constitucional sobre lei ou ato normativo federal, estadual ou municipal, incluídos os anteriores à Constituição (BRASIL, 1999).

Contudo, a questão da transição não pode ser predicada apenas em uma semântica - jurídica - e em uma temporalidade - cronológica. Refletir sobre a transição impõe o entrelaçamento entre o direito e a política - e o reconhecimento da inafastabilidade desta textura. Demanda, de igual maneira, a compreensão de que as decisões políticas são kairológicas, que elas possuem um momento oportuno, um momento certo, muitas vezes, fugidio. Por isso, a transição possui temporalidade diferenciada de outros temas políticos, já que nem sempre as vias para a sua concretização se encontram abertas. (OST, 2005). Assim,

${ }^{1} \mathrm{O}$ dispositivo recomendado para o questionamento da legislação anterior à Constituição Federal de 1988 é a Arguição de Descumprimento de Preceito Fundamental, sobre o tema ver: Clève e Dias (2001).

Revista do Direito Público, Londrina, v.10, n.3, p.9-30, set./dez.2015 | DOI: 10.5433/1980-511X.2015v10n3p9 
observa-se que, se por um lado existem transições políticas que são realizadas logo após a retomada das instituições democráticas, por outro, nem sempre aquilo que se almeja concretizar - a passagem de um regime autoritário para um regime democrático - pode ser alcançado. Por isso, observam-se transições tardias, extemporâneas, mas, tão importantes quanto aquelas realizadas na sequência da queda dos regimes autoritários.

Esta variação temporal possui uma mácula, pois está refletida no maquinário burocrático e simboliza o grau de colonização nefasta produzida pela ditadura. Leia-se, representa até que ponto a corrupção institucional foi realizada e indica o grau de resgate (ou estabelecimento) que se faz necessário dos mecanismos democráticos.

Se, em uma primeira mirada o poder constituinte pode parecer um problema jurídico e a justiça de transição um problema político, aquilo que se procurará expor é que o assunto não pode ser trabalhado como simples caminho de vetores, uma vez que se assume a presença inafastável de categorias políticas na confecção do(s) Direito(s) e, no sentido inverso, a necessidade de categorias jurídicas para a solução de problemas políticos ou morais, inclusive no sentido de afastar as práticas dos regimes democráticos daquelas atribuídas aos regimes autoritários.

Sobre a tensão direito e política afirma Clèmerson Merlin Clève (2011, p. 139) que:

A tentativa de recuperar o político para o direito é a proposta epistêmica mais interessante, embora ambiciosa, do pensamento crítico voltado para o 'jus'. Não se trata de fazer nova teoria jurídica com pretensão de substituir as escolas jurídicas tradicionais. Do contrário, procura-se criar renovada dimensão para o discurso jurídico, de tal modo que, além das preocupações instrumentais, possa ele conhecer o seu objeto como algo inserido na história.

\section{PODER CONSTITUINTE}

A questão atinente ao poder constituinte se entrelaça com a justiça de transição na medida em que ocupa o papel de dínamo que habilita a mudança entre regimes. Se os conceitos relacionados à justiça de transição possuem leituras díspares e posicionamentos de diferentes tipos e graus em relação à sua adesão ou não, sua eficácia, seus limites, de igual modo o poder constituinte se coloca sob um vértice, em que extremos de dois lados nem sempre se comunicam. 
Para Cármen Lúcia Antunes Rocha, a noção de poder constituinte é originária:

[...] no sentido de que não se apega, não se vincula e nem se limita a padrões políticos-jurídicos anteriormente vigentes ou impostos por qualquer forma a esse povo. Daí por que não Teoria da Constituição se tem por certo que um povo deflagra o processo constituinte originário quando não dispunha, ainda, de uma ordem jurídica soberana, uma vez que o Estado independente acaba de surgir advindo de outro (formação derivada de Estado, por separação ou união a outro), e, então, ao constituir-se em entidade política soberana, precisa elaborar o seu Direito; ou quando, a despeito de ter tido um sistema constitucional, não o tem mais como legítimo, não pretendendo, então mantêlo vigente, pelo quê o faz substituir por outro (ROCHA, 2001. p. 378).

O poder constituinte originário pode ser observado a partir de diferentes prismas. É possível colocar ênfase nas mobilizações sociais que o precedem, as demandas populares que procuram formar a nova identidade constitucional de um determinado povo. Igualmente oportuna é a mirada sobre o processo de positivação das novas normas que irão reger o ordenamento jurídico. Ainda, também é possível tratar das consequências decorrentes da implantação da nova regra de reconhecimento.

Para além de um simples processo jurídico, monológico, o poder constituinte se encontra necessariamente enredado pela tensão entre a democracia e o constitucionalismo. Ainda, outras questões podem ser suscitadas, como a própria legitimidade para a sua formação. (ACKERMAN, 1993; MÜLLER, 1998).

É possível afirmar que a "elaboração formal da Constituição demarca um momento jurídico definitivo - o da modelação normativa na qual se contém a opção política do povo [...]" (ROCHA, 2001, p. 378), ainda que existam sinceros questionamentos a respeito da extensão do "definitivo", no âmbito político o problema instituinte não fica resolvido. Não apenas pela questão da eficácia normativa superveniente, mas pela legitimidade política do processo de produção e interpretação das normas constitucionais.

Ainda, se juridicamente formula-se uma demanda por estabilização, politicamente trata-se justamente da desestabilização, da formação de novas normas, da produção incessante da identidade constitucional de uma determinada comunidade política, que não se estanca no momento de início da produção constitucional, pelo contrário, aquilo que há de definitivo no processo constituinte 
é o "início", porém, os ajustes políticos, as demandas populares, os pleitos de gerações futuras, não podem ser atados para sempre por um texto constitucional.

Essa a razão pela qual o processo constituinte não se extingue com a promulgação do novo sistema constitucional. A transição é que garante a integridade da implantação institucional da Constituição, permitindo fazer valer as novas normas e dotando de eficácia a inteireza do sistema que nela se contém (ROCHA, 2001, p. 379).

Outra questão pode ser colocada no plano semântico. Se a transição constituinte, em que foi realizada a negociação política e jurídica com os membros do regime anterior postulava o risco de uma "crise constituinte permanente", a justiça de transição não possui o mesmo problema, uma vez que trata de fazer justiça (em sentido amplo) com o passado, e o poder constituinte perfila como um dos seus possíveis elementos.

\subsection{Poder Constituinte como Agrilhoamento}

Dentre as várias possíveis, uma leitura a respeito do poder constituinte pode ser realizada a partir da obra de Jon Elster que utiliza como metáfora para sua teoria da racionalidade imperfeita dos atores sociais, a figura de Ulisses acorrentado ao mastro de seu barco, e assume que este não era completamente racional, mas possuía em seu favor a consciência de que era fraco, falível. Logo, o autor, em sua obra "Ulisses e as sereias", expõe que: “[...] as sociedades, assim como os indivíduos, entenderam que era útil se acorrentar [...]" (ELSTER, 1993, p. 37, tradução livre) como no caso da promulgação de constituições.

Como explica Roberto Gargarella, a transferência desta metáfora ao plano constitucional parece óbvia: “[...] do mesmo modo em que Ulisses pode ganhar liberdade, ao invés de perdê-la, ao se incapacitar para certas ações, uma sociedade também pode expandir suas capacidades ao se auto-impor determinados limites" (GARGARELLA, 2008, p. 30).

O papel da Constituição seria, de acordo com esta perspectiva, o de impor limites capacitadores sobre os poderes de autogoverno da sociedade. Ao reconhecer que esta ação suporta riscos, como a opressão de grupos minoritários, a censura de partidos opositores, a ação racional de uma sociedade precisaria demarcar certos limites irrenunciáveis, com a capacidade de aprimorar a liberdade das gerações futuras.

De imediato, surgem questões que tratam de problemas da prática do "acorrentamento" (bindingoneself) em outros ramos como: "quem acorrenta 
quem?" e “quem tem o direito de acorrentar quem?". Elster dá o exemplo de que, para parar de fumar, as pessoas usam meios que acrescentam força a esta resolução interna, com vistas a manter este pré-compromisso. Deste modo, a autopunição surge como uma das técnicas de autocontrole (GARGARELLA, 2008, p. 39).

Figurativamente, faz-se possível imaginar o mastro do navio ou a Constituição de um país como a estrutura externa que agrilhoa vontades por um tempo determinado. Esta característica seria, para Elster, intrínseca ao ser humano, apenas o homem possui a capacidade de superar suas fraquezas através do uso de técnicas como o pré-compromisso.

Contudo, o pré-compromisso não é tão simples quando se procura transpor o planejamento (racional-estratégico) para o campo social, pois se, por um lado, os indivíduos são livres para se agrilhoar por meio de leis, como cintos de segurança, contra seus arroubos impulsivos, por outro lado, sérios problemas surgem quando estas restrições são impostas aos indivíduos, contra sua vontade anterior (GARGARELLA, 2008, p. 84).

Desse modo, descortina-se outro viés presente na embarcação de Ulisses, a política, eis que, uma democracia, segundo Elster, pode rumar por águas incertas, com a constante reavaliação de planos do passado, de modo a se aproximar da inconsistência e a ineficiência (GARGARELLA, 2008, p. 88).

Com a preocupação de manter a democracia nos limites exigidos para sua eficiência e estabilidade, foram criadas, nas democracias modernas, instituições, as quais podem ser interpretadas como dispositivos de précompromisso. Assim, através das instituições é possível identificar, com níveis de precisão distintos, quando os políticos (originários) decidiram que certos valores eram muito importantes, ou certos instrumentos muito perigosos, para serem sujeitos ao controle dos políticos (futuros) (GARGARELLA, 2008, p. 90).

O exemplo de instituição que se amolda à descrição de Elster são as Constituições modernas, que incorporaram princípios que constituem o núcleo duro dos Estados democráticos de Direito, em um movimento que teve início após a Segunda Guerra Mundial, mas que já possuía exemplos (e os incorporou) nas Constituições e Declarações de Direitos do século XVIII, frutos da revolução americana e francesa (ARENDT, 2009).

Por isso, a Assembleia Constituinte passa a ter um papel fundamental. No entendimento de Elster, ela dispõe as normas fundamentais que deverão ser seguidas por todas as gerações futuras e, além disso: "Apenas a assembléia constituinte realmente é um ator político, no sentido forte da la politique 
politisante; todas as futuras gerações estão restringidas a la politique politisée, ou a atuação do dia-a-dia com as normas fundamentais" (ELSTER, 1993, p. 93).

Assim, um Estado pode se agrilhoar por meio de uma Assembleia Constituinte, ao garantir poderes de decisão ao judiciário, e demandar um quórum elevado para a promoção de mudanças de normas fundamentais. Mas, disso surge, de maneira inevitável, um paradoxo, qual seja, cada geração almeja possuir a liberdade para atar seus sucessores, enquanto ocupa a posição de liberdade ante seus predecessores. ${ }^{2}$

Para Elster a estratégia de Ulisses é a de acorrentar as gerações futuras ao se estabelecer uma Constituição que inclua cláusulas que dificultem sua fácil alteração. Logo, a Assembleia Constituinte possui um caráter único e privilegiado, que não é fundado em qualquer direito, mas por causa de um "acidente histórico" (ELSTER, 1993, p. 94).

Em casos raros, os constituintes deixam questões fundamentais do corpo constitucional em aberto para decisões das futuras gerações. No caso do Brasil, a Constituição de 1988 trouxe no Ato das Disposições Constitucionais Transitórias $^{3}$ a previsão de um plebiscito, a ser realizado em 1993, para a população decidir entre a forma, República ou Monarquia, e o sistema de governo, Presidencialismo ou Parlamentarismo (BRASIL, 1988). Entende-se que este exemplo não é apropriado para pensar a questão das gerações futuras, pois, na verdade, praticamente as mesmas pessoas que participaram do processo de abertura democrática do país, foram as que votaram no plebiscito, ou seja, não constituíram uma geração posterior.

Mas não deixa de ser interessante que teóricos políticos levaram a sério a questão de Assembleias Constituintes periódicas, de maneira que todas as pessoas, ao menos uma vez na vida, tivessem a oportunidade de decidir sobre os direitos fundamentais que regeriam a sociedade em que vivem, ao invés de depender da herança política de gerações passadas (JEFFERSON, 1973; ACKERMAN, 1993).

${ }^{2}$ Este problema também se encontra na teoria do véu de ignorância de John Rawls. (BARRY, 2001).

3 Como explica Cármen Lúcia Antunes Rocha: “As disposições transitórias não têm conteúdo de igual teor fundamental para a sociedade estatal, no sentido de constituir as instituições basilares da organização do Estado, ou de reconhecer e garantir direitos fundamentais para os indivíduos e grupos sociais. A matéria cuidada nas disposições transitórias caracteriza-se exatamente por não ser fundamental a ponto de ter sido contemplada nas normas constitucionais do corpo permanente ou de ter ali recebido tratamento diferenciado. Daí por que elas cuidam de situações merecedoras de uma prescrição específica, porém precária, e apenas como etapa sócio-política a ser superada sem traumas políticos ou jurídicos, por assim entender melhor o poder constituinte originário." (ROCHA, 2001, p. 393). 
Elster deu continuidade a sua teoria do pré-compromisso e aprofundou o debate, após as críticas sofridas pela sua obra inicial. Em sua obra "Ulisses liberto", (ELSTER, 2000) dedicou todo um capítulo para o debate da relação entre constituições e suas possíveis "amarras".

Reiterou que constituições políticas podem ser usadas como dispositivos de pré-compromisso ou auto-restrição, criadas pelo corpo político com a finalidade de se proteger contra sua própria tendência de tomar decisões equívocas. Mas, expôs a ressalva de que alguns dispositivos que estão disponíveis para o agrilhoamento dos indivíduos não podem ser usados para a coletividade, assim como algumas razões que motivam os indivíduos a realizarem précompromissos, podem não possuir qualquer sentido análogo no caso da Constituição (ELSTER, 2000, p. 90).

Logo, a metáfora de Ulisses para o processo de criação de constituições é apenas válida de maneira parcial, além do que, a ideia de uma sociedade se agrilhoando é, no mínimo, controversa. Pois, se de um lado as constituições podem atar outras pessoas, como o caso de gerações futuras, ao invés de serem atos de constrição própria; por outro lado, elas podem não deter o poder para conseguir atar qualquer coisa.

A estrutura das constituições prevê que a Carta Magna deve ocupar um lugar superior em comparação com a legislação ordinária, por isso, costumeiramente, são moldadas para dificultar a mudança de seus respectivos textos, com a adoção, por exemplo, de quóruns qualificados. Porém, a produção de emendas não é impossível. Embora alguns temas das constituições possam se encontrar em uma disposição especial na organização sistêmica desta, como a impossibilidade de mudança do texto de artigos fundamentais ou da estrutura da própria Constituição, Elster lembra que a ação extra-constitucional sempre continua possível (ELSTER, 2000, p. 94). A partir disso, entende-se que, mesmo este "núcleo duro" seria passível de mudanças.

No desenvolvimento de sua teoria do pré-compromisso, o autor expõe que tentativas de atar a sociedade de maneira muito estreita podem ser problemáticas, pois, teriam o potencial de produzir efeitos contrários, ou seja, os cidadãos podem reagir à própria ideia de serem acorrentados a determinadas instâncias de poder, podendo se rebelar contra esta (ELSTER, 2000, p. 95).

Basta lembrar que no repertório das motivações usadas pelas colônias europeias para demandar libertação, tendia a surgir no discurso: a opressão, a falta de legitimidade, a ausência de identificação e a necessidade de autonomia, 
ou seja, de produção das próprias regras, independentemente de um poder "exterior".

Apesar dos problemas decorrentes de amarras muito apertadas, o papel do constitucionalismo seria de importância significativa, eis que, caberia a ele assegurar uma mudança cadenciada da Constituição. Além disso, incumbiria à Constituição a regulação da vida política, como a criação do próprio ordenamento jurídico em que irá se assentar. Assim, desde uma perspectiva liberal, competiria à carta de direitos a proteção dos cidadãos da interferência indevida do governo, bem como regular a máquina de governo, através do estabelecimento do modo de eleição e representação, as funções do governo, a separação de poderes, freios e contrapesos, entre outros (ELSTER, 2000, p. 100).

Outro problema enfrentado por Elster diz respeito ao fato de que, se as constituições partem de uma Assembleia Constituinte, deveria esta ser submetida a limitações e a pré-compromissos? (ELSTER, 2000, p. 105). O debate neste ponto parece se aproximar ao problema da necessidade de um fundamento último para a legitimação de corpos legislativos, pois, as Assembleias Constituintes não poderiam, em tese, criar-se espontaneamente, puxar os cadarços da própria bota para sair do pântano (ELSTER, 1994).

Porém, Elster joga luz sobre a questão para mostrar que, no início do debate sobre as constituições modernas, enquanto uma corrente entendia que era auto-evidente o fato da Assembleia não possuir poderes para destruir ou limitar seu criador, como, por exemplo, o rei. Para outros, contudo, era também evidente que a assembleia poderia fazer aquilo que bem desejasse, pois era a incorporação da vontade da nação (ELSTER, 2000, p. 109).

Exatamente nesse tópico, a questão do "paradoxo da democracia" ressurge de maneira exponencial. Enfrenta-se, em um polo, a assembleia que, na medida do possível, procura se libertar do passado, de todos précompromissos que a precederam. No outro pólo, almeja o poder de criação normativa que se estenda sobre as gerações futuras, com a garantia de que elas estarão agrilhoadas de tal modo que não será fácil libertar-se da herança legada por eles (ELSTER, 2000, p. 115).

Em consonância com o "paradoxo da democracia", em que uma geração procura se libertar, mas, acorrentar as futuras, Elster trata do paradoxo da onipotência. Se a relação com os "pais fundadores" é, no mínimo, turbulenta, a relação dos poderes no caso da onipotência de um deles pode ser dramática. Por isso, defende o autor que: “[...] o poder, para ser efetivo, deve ser divido; e 
a onipotência, longe e ser uma benção, pode ser uma maldição" (ELSTER, 2000, p. 146, tradução livre).

O golpe final que Elster desfere em sua teoria anterior é o seguinte: se em "Ulisses e as sereias" ele havia se aproximado da ideia de que as constituições poderiam ser observadas como dispositivos de pré-compromisso, e que as sociedades deveriam se acorrentar com elas, "[...] estas afirmações são eminentemente contestáveis, nos planos conceitual, causal e normativo" (ELSTER, 2000, p. 167).

A ideia de pré-compromisso constitucional possui, portanto, sua legitimidade agravada pelo fato de que nenhum grupo social detém o direito de, em nome de todos, arrogar-se a representação do interesse geral. O problema que decorre disso é a imposição das constituições a minorias e a gerações futuras, a partir do interesse da maioria ou da "primeira" geração.

Como lembra Elster, as futuras gerações não possuem poder de barganha, sua única esperança é a de que os constituintes se preocupem com seus descendentes e alguns de seus interesses futuros (ELSTER, 2000, p. 170). Em última nota, procura salvar aquilo que resta da sua teoria, em seu aspecto da racionalidade imperfeita, ao afirmar que não é possível esperar que constituintes imperfeitas criem constituições perfeitas que irão lidar com as imperfeições dos futuros políticos.

\subsection{O Poder Constituinte no Brasil}

No caso do Brasil, a Assembleia Nacional Constituinte almejou realizar uma profunda reforma da máquina estatal, porém, esta foi interrompida por interesses das elites que ali se fizeram representadas. Ante a possível radicalidade de uma mudança institucional, levantaram-se grupos de interesse que assombraram e limitaram o potencial transformativo presente no poder constituinte. O saldo positivo é que se tem uma Constituição em que acabou por prevalecer (não em sua totalidade, mas em um grande número de ocasiões), uma postura progressista circunscrita a uma minoria parlamentar, face à maioria conservadora. Observa-se, portanto, na atual Constituição as diferentes vozes que no momento donovopacto institucional puderam se fazer ouvir.

De acordo com Adriano Pilatti:

Ao encerrar formalmente o longo processo de transição democrática que se iniciou no final dos anos 1970 em nosso País, a Assembléia Nacional Constituinte em 1987-1988 (ANC) foi palco de grandes conflitos de interesse 
e opinião que haviam permanecido latentes, irresolutos ou agravados, durante os anos de repressão. Tais conflitos ensejaram mobilizações de intensidade e extensão inéditas na história das Constituições brasileiras. Entre $1^{\circ}$ de fevereiro de 1987 e 5 de outubro de 1988, o edifício do Congresso Nacional, em Brasília, transformou-se em ponto de afluência de múltiplos setores organizados da sociedade brasileira. Ali aconteceu um processo decisório caracterizado pelo dissenso, pela intensa e permanente mobilização de atores coletivos internos e externos, por votações altamente polarizadoras e, ao mesmo tempo - sobretudo em sua fase final -, por uma atividade igualmente intensa e incessante de busca de acordos entre as lideranças das diferentes forças em choque. (PILATTI, 2008. p. 1).

Mas, aquilo que possibilitou a convocação da Assembleia Constituinte foi uma crise anterior da ditadura militar que, no plano da legitimidade política, perdera diuturnamente suas forças na década de 1980. A lenta transição institucional, decorrente da repercussão das manifestações populares nas ruas do país, não correspondeu ao ritmo pulsante do povo,o qual almejava democracia depois de tanto tempo sem desfrutá-la.

No âmbito institucional, a transição foi refreada, postergada, esfriada de diversas maneiras. A coalização do velho regime e de forças moderadas conduziu a uma "transição com transação", sem rupturas violentas. Reencarnando uma auto-imagem nacional do brasileiro como um ser dócil, pacífico, cordial, mesmo após todos os anos de chumbo.

Daniel Sarmento e Cláudio Pereira de Souza Neto lembram que:

No processo político que se desenvolveu no país, o início da transição decorreu de iniciativa de elementos do próprio regime autoritário, que, durante a sua fase inicial, ditaram o seu ritmo e impuseram os seus limites. As forças do regime autoritário, mesmo depois de perderem o protagonismo no processo histórico de redemocratização, mantiveram um amplo poder de barganha, e até mesmo de veto (SOUZA NETO; SARMENTO, 2012.p. 156).

Uma crítica bastante importante voltada ao processo anterior à Assembleia Constituinte diz respeito ao fato de a constituinte não possuir uma eleição específica para a composição de seus membros, utilizando-se, portanto, daquele corpo legislativo já existente, proveniente ainda de eleições indiretas, simbolizados pelos senadores empossados no ano de 1982, os quais não possuíam qualquer legitimidade democrática e não eram legítimos representantes do povo. Preferia-se uma "constituinte exclusiva" composta por membros não vinculados 
ao regime institucional ditatorial, com regras eleitorais próprias, que não seguissem a estrutura eleitoral da ditadura.

Lembra Adriano Pilatti (2008, p. 25-26) que:

A impugnação à participação dos senadores eleitos em 1982 deu-se através de questão de ordem levantada pelo deputado Plínio Arruda Sampaio (PT), seguida de outra, com o mesmo objetivo, levantada pelo deputado Roberto Freire (PCB). [...] O presidente Moreira Alves afirmou preliminarmente sua própria competência para decidir sobre as questões de ordem, por considerálas exclusivamente atinentes à eleição do presidente da ANC. Invocou os termos do art. $1^{\circ}$ da EC-26/85 e decidiu o seguinte: Como o texto salienta que são os membros da Câmara dos Deputados e do Senado Federal que se reunirão em Assembléia Nacional Constituinte, esta Presidência decide que os senadores eleitos em 1982, que continuam no exercício de seu mandato, têm direito de voto nesta eleição."

Outros dois pontos controvertidos versam sobre: a) a Comissão Afonso Arinos, formada por personalidades renomadas, representantes de diferentes posições ideológicas, mas que acabou por não ser utilizada pelo Presidente Sarney, que não a enviou à Constituinte, tendo seus trabalhos arquivados no Ministério da Justiça, limitando-se a servir de influência para a Constituição de 1988; b) um problema de ordem teórica, de posição minoritária e distorcida que defendia que à Constituinte não caberia o exercício do poder constituinte originário, pois, aquilo que acontecia tratava-se de poder constituinte derivado, o qual seria limitado pela norma superior que o convocara.

Por fortuna, os cantos de mau agouro não vingaram sobre a Constituinte, prevalecendo o entendimento de que a mesma era legítima, pois resultado proveniente das manifestações populares e das lutas pela democracia que fizeram parte do cenário político nacional da época. Como afirmam Sarmento e Souza Neto: "Do ponto de vista histórico, a Constituição de 1988 representa o coroamento do processo de transição do regime autoritário em direção à democracia" (SOUZA NETO; SARMENTO, 2012, p. 170).

\section{A JUSTIÇA DE TRANSIÇÃO NO BRASIL}

As diferentes formas de transição constitucional podem ser observadas a partir de uma estrutura da justiça de transição. Conforme apontado anteriormente, a transição ocorrida no Brasil foi negociada, pactuada entre os 
membros do regime militar com aqueles que seriam os novos componentes do regime democrático. A questão de fundo, que perpassa o problema da transição, é o de como consolidar novas instituições e constituições democráticas? Adicionalmente, como lidar com o passado, com os atores políticos que perpetraram mazelas contra a população, os "malfeitores"? Como reconstruir estruturalmente e economicamente um país após uma ditadura? Seria o caso de julgar, condenar, bloquear a influência política daqueles que estavam ligados aos regimes anteriores?

As respostas que a história apresenta são plurais. Cada sociedade, em sua especificidade, cultura e em seu momento histórico apresentaram diferentes soluções para demandas tão incisivas. Deve-se tomar conhecimento que a resposta pautada na pura legalidade é apenas uma dentre aquelas constantes em um amplo leque de modalidades diferenciadas apresentadas ao longo da história.

Neste sentido, Jon Elster fornece um conceito sintético e abrangente de justiça de transição: "A justiça de transição é formada por processos de julgamentos, expurgos e reparações que tomam lugar depois da transição de um regime político para outro." (ELSTER, 2004, p. 1, tradução livre). Em específico, no que tange às transições realizadas na década de 1980 na América Latina, pode-se observar que boa parte de delas foi negociada por regimes militares desgastados que procuraram, em certos casos com relativo sucesso, assegurar uma futura imunidade para os seus membros.

No caso do Brasil, em 1979 foi promulgada a Lei da Anistia (Lei 6.683/ 1979) pelo Presidente João Figueiredo, a qual é considerada uma auto-anistia, pois os governantes ligados ao regime militar continuaram no poder e a abertura democrática tardou ainda mais uma década para se concretizar.

$\mathrm{Na}$ classificação dos diferentes tipos de transição, um dos pontos importantes é a identificação da natureza e da duração do regime ditatorial, além da duração e da natureza do próprio processo de justiça de transição. Ambos podem ser: exógenos ou endógenos, de longa ou curta duração.

De acordo com Elster (2004), os casos mais importantes são os em que a endogenia ocorre de maneira dupla, os regimes opressores são endógenos assim como a forma pela qual a justiça de transição é processada. Pois, nestas circunstâncias, a sociedade precisa realizar um pacto, um acerto de contas com ela própria:

Em uma metáfora em que eu também usei para descrever o processo de produção de constituições em novas democracias, a sociedade precisa se 
reconstruir em mar aberto, usando dos materiais à mão, por mais defeituosos que eles possam ser. Mesmo quando juízes, por exemplo, estavam profundamente envolvidos com o regime pré-democrático, pode não haver uma alternativa prática que o uso deles, ou, ao menos, daqueles menos comprometidos entre eles, para julgar o próprio regime (ELSTER, 2004, p. 75).

Se for considerada a dimensão temporal do regime de transição, pode-se tratar de uma justiça de transição imediata, em que a reconstrução da sociedade ocorre logo após a derrocada do regime ou, prolongada, em que se postergam os efeitos práticos da transição, mantendo no poder figuras políticas ligadas ao regime anterior.

Ademais, pode-se falar em uma segunda onda da justiça de transição, na qual se tem um período de latência no qual poucas ações são tomadas ou nenhuma medida é adotada pelo governo até que, após anos, perante uma conjuntura política favorável, os processos de transição são retomados.

Para o Brasil, não é possível dizer que os governos democráticos foram completamente omissos em relação ao tema da justiça de transição. Medidas institucionais foram adotadas por diferentes governos buscando atenuar as interferências políticas e institucionais dos agentes ligados ao regime militar.

Porém, aquilo que pode ser observado é o reaquecimento do debate em torno da questão da justiça de transição em razão de uma decisão abertamente política do governo federal em relembrar os crimes cometidos durante a ditadura militar, além da procura pelo aperfeiçoamento dos mecanismos administrativos ligados à informação, à transparência, à democratização e ao aperfeiçoamento da própria máquina governamental nos últimos cinco anos. Aproximando, portanto, o país da experiência de uma segunda onda.

Um dos pontos que qualificam a distinção na justiça de transição entre o regime passado e o presente é que, via de regra, o presente procura não reproduzir os erros do passado. Se as atrocidades foram cometidas anteriormente para além da lei, há uma busca pela autorização jurídica para a punição dos agentes do regime.

Aqui surge um problema, pois, a preocupação em se afastar do regime anterior, traçando uma importante linha legitimadora entre os governos, acaba por limitar os meios punitivos disponíveis em um Estado Democrático de Direito para a condenação dos "malfeitores" do passado. Seria necessário o recurso a leis retroativas e abraçar práticas ilegais também adotadas pelo regime anterior, por exemplo. 
Por razão deste problema, Elster trata das instituições da justiça, expondo que existem diferentes formas de fazer justiça, no plano legal, administrativo e político. Uma justiça puramente política ocorre no caso em que o executivo, de modo unilateral designa os "malfeitores" e decide aquilo que deve ser feito com eles. Uma justiça puramente jurídica, caracteriza-se pela garantia dos princípios do devido processo legal, tais como, por leis que não sejam ambíguas, juízes e jurados imparciais, direito à ampla defesa, sem retroação da lei, determinação individual da culpa, etc. A justiça administrativa, estruturalmente é muito similar à jurídica e deveria respeitar os mesmos requisitos (ELSTER, 2004).

O resultado final de uma transição acaba por expor uma série de decisões de ordem política, administrativa e jurídica. No caso das transições negociadas, como aconteceu no Brasil, algumas opções políticas podem ficar de fora da transição para que a mesa de negociações possa ter continuidade e que os termos da entrega do poder sejam estabelecidos. Contudo, no caso pátrio, aquilo que restou observado foi uma auto-anistia jurídica, com negociações posteriores a respeito da abertura democrática.

Dentre as plurais decisões a serem tomadas no momento da transição encontra-se a necessidade de se apontar quem e quais fatos devem ser tidos como transgressores. Na sequência, surge o problema de como tratar os "malfeitores" estabelecidos, ante um amplo rol de punições e perda de direitos além de condenações de ordem moral, como a perda da condição de "vítima". Mesmo quando os oficiais não são levados a um tribunal, o novo regime pode decidir impor sanções. A compensação das vítimas também aparece de forma bastante abrangente, de acordo com os danos cometidos a elas, de ordem material (perda de bens), pessoal (violação de direitos fundamentais) ou intangível (perda de oportunidades).

No caso pátrio, o Presidente Fernando Henrique sancionou uma das primeiras leis no sentido de contribuir para a construção de uma justiça de transição no Brasil, qual seja, a Lei 9.140/1995, que reconheceu como mortas as pessoas desparecidas durante o período da ditadura militar. Em seu art. $1^{\circ}$ dispõe que:

São reconhecidos como mortas, para todos os efeitos legais, as pessoas que tenham participado, ou tenham sido acusadas de participação, em atividades políticas, no período de 2 de setembro de 1961 a 5 de outubro de 1988, e que, por este motivo, tenham sido detidas por agentes públicos, achando-se, deste então, desaparecidas, sem que delas haja notícias (BRASIL, 1995). 
A referida Lei previa a criação de uma "Comissão Especial" para reconhecer as pessoas desaparecidas, localizar os corpos e emitir parecer sobre os pedidos de indenização. Observa-se que, apesar de constar previsão sobre a indenização, a mesma foi formulada de maneira restritiva, passando a ter caráter mais abrangente na legislação estabelecida posteriormente.

Assim, o Presidente Fernando Henrique editou a Medida Provisória n. $65 / 2002$, convertida na Lei 10.559/2002 que dispôs sobre o regime do anistiado político e seus direitos, dentre eles compreendidos: a reparação econômica de caráter indenizatório; conclusão de curso para o punido na condição de estudante; reintegração de servidores públicos civis e dos empregados públicos.

Em 2008, obteve-se mais uma conquista no sentido da reconstrução da memória daqueles que sofreram com o regime da ditadura militar no Brasil. $\mathrm{O}$ primeiro oficial ligado ao regime, o Coronel Carlos Alberto Brilhante Ustra, foi condenado em ação declaratória por sequestro e tortura. O juiz Santini Teodoro atendeu ao pedido formulado pela família Teles e reconheceu a relação jurídica existente entre a família Teles e o Coronel, a qual foi derivada da prática da tortura. Neste caso não houve demanda por indenização ou punição. O marco simbólico da referida decisão foi importante no sentido de o Estado brasileiro reconhecer e condenar, pela primeira vez, um importante agente "malfeitor" ligado à ditadura militar. Em 2012, o mesmo Coronel foi condenado em outra ação, no caso, de indenização por danos morais, a pagar $\mathrm{R} \$ 100.000,00$ aos familiares do jornalista Luiz Eduardo Merlino, por ter comandado e participado das sessões de tortura que resultaram na morte do membro do Partido Operário Comunista.

Mesmo com práticas anteriores importantes no sentido da construção de uma justiça de transição no Brasil, o tema se tornou uma pauta de governo, com medidas concretas e instituições específicas sob o governo do Partido dos Trabalhadores, iniciado pelo Presidente Lula e continuado, com verticalizações,por Dilma Rousseff.

No período do governo Lula, os Ministros da Justiça, da Secretaria Especial de Direitos Humanos e o Presidente da Comissão da Anistia defenderam publicamente o afastamento da Lei n. 6.683/1979 (Lei da Anistia) para os agentes públicos que tinham cometido violações a direitos humanos. Ainda, ampliaram-se as políticas de reparação com os projetos "Direito à Memória e à Verdade", "Marcos da Memória", "Memórias Reveladas" e as "Caravanas da Anistia", com vistas a contribuir para mais uma faceta da justiça de transição, qual seja, a construção da memória e a busca pela verdade. 
Na continuidade das políticas anteriores, Dilma Rousseff editou duas importantes Leis em 18 de novembro de 2011: a Lei 12.527, que estabeleceu uma nova regulamentação para o acesso à informação e a Lei 12.528, que criou a Comissão Nacional da Verdade.

A nova lei de acesso à informação promoveu importante revisão nas categorias dos documentos públicos, porém, aquilo que aparenta ser mais importante é a mudança no fundamento que norteia as ações do Estado a partir de então, qual seja, a adoção da transparência como critério a ser seguido por todos os entes públicos, legando o sigilo a questões excepcionais. Não é possível dizer que a Lei n. 12.527/2011 tenha sido inovadora per se, face a existência de dispositivos jurídicos anteriores que procuravam atender as disposições constantes na Constituição Federal de 1988.

A Comissão Nacional da Verdade, por sua vez, também se coloca no sentido de promover valores democráticos na reconstrução do Estado brasileiro após a ditadura militar. Ainda que tardia, e sem poderes para punir aqueles que venham a ser identificados como "malfeitores" do regime militar, é mais um importante pilar na arquitetura de poderes públicos que respondem publicamente pelos seus atos, que prestam contas de suas ações - accountability - e que não soterram o passado, estimulando a construção da memória, da verdade e primando pelo respeito aos direitos humanos.

Por último, importante se faz mencionar o julgamento da ADPF n. 153 no STF em 2010. A OAB demandou perante o STF através de Arguição de Descumprimento de Preceito Fundamental que a Lei da Anistia fosse submetida a uma interpretação conforme a Constituição, de maneira a reconhecer, perante a influência inafastável dos direitos fundamentais da composição da ordem normativa nacional, que a anistia concedida aos crimes políticos ou conexos não poderia abranger os crimes comuns praticados por atores políticos da ditadura militar contra opositores do regime.

Aduziu a OAB que o seguinte dispositivo: "art. $1^{\circ} \S 1^{\circ}$ - Consideram-se conexos, para efeito deste artigo, os crimes de qualquer natureza relacionados com crimes políticos ou praticados por motivação política" (BRASIL, 1979), da Lei da Anistia não teria sido recepcionado pela Constituição Federal, a qual trata o crime de tortura como não passível de graça ou anistia, nos termos do art. $5^{\circ}$, XLIII da CF. Ademais, a OAB trouxe jurisprudência da Corte Interamericana de Direitos Humanos que já havia decidido pela nulidade das auto-anistias criminais decretadas unilateralmente por governantes. Porém, 
conforme explicam Daniel Sarmento e Cláudio Pereira de Souza Neto (2012, p. 453), o julgamento foi o seguinte:

Como esses, houve diversos casos em que o Direito Internacional dos Direitos Humanos foi invocado pelo STF no exercício da interpretação constitucional. Sem embargo, há casos também em que a orientação internacional não é seguida. Isso aconteceu recentemente no Brasil, quando se discutiu a recepção da Lei de Anistia pela Constituição de 1988, na parte em que garantira a impunidade dos agentes do regime que cometeram graves violações de direitos humanos durante o regime militar. A jurisprudência da Corte Interamericana era pacífica sobre a incompatibilidade dessas anistias com a Convenção Americana de Direitos Humanos. Nada obstante, o STF considerou recepcionada toda a Lei da Anistia, afastando-se da linha adotada no Direito Internacional dos Direitos Humanos. Posteriormente à decisão do Supremo, a Corte Interamericana proferiu decisão no caso Gomes Lund v. Brasil, reconhecendo a incompatibilidade da anistia em questão com a Convenção Americana. Há atualmente uma certa celeuma sobre qual das duas soluções deve prevalecer, pendendo de apreciação do STF [...] os embargos de declaração opostos pelo Conselho Federal da $\mathrm{OAB}$ em que se busca o esclarecimento deste ponto.

Em suma, o que resta ainda, "no ar" é um impasse entre a decisão proferida pelo STF e a jurisprudência da Corte Interamericana de Direitos Humanos. E, ainda, outro paradoxo a respeito do assunto está na decisão anterior (2009) da própria Suprema Corte no sentido de extraditar o Coronel uruguaio Manuel Cordeiro Piacentini para a Argentina por seu envolvimento na Operação Condor. Contudo, sabe-se que, até o momento o Supremo Tribunal Federal não se preocupou em formular uma dimensão de justiça como integridade ou a construção de um "romance em cadeia" em sua jurisprudência (DWORKIN, 1999).

Afirmou-se, anteriormente, que a política é também regida por uma temporalidade diversa, kairológica, não puramente cronológica. Existem momentos fugidios em que as decisões políticas são tomadas, oportunidades que surgem em determinado instante e que não irão se repetir. Assim, podese observar este momento no que tange à justiça de transição, no plano político presente, em que o governo federal resolveu verticalizar as ações ligadas à reconstrução institucional do país, principalmente no plano legislativo e administrativo, adotando diversas políticas públicas para: i) a promoção da memória; ii)a busca pela verdade; iii) o não esquecimento 
daquilo que aconteceu durante a ditadura, e iv) possibilitar o acesso à informação.

Porém, no que tange ao judiciário, este momento ainda não surgiu, pois, se o julgamento do Coronel Ustra foi simbolicamente importante, a decisão da ADPF 153 contrariou as expectativas, ao passo que o próprio governo (por meio da $\mathrm{AGU}$ ), posicionou-se de maneira contrária ao pleito formulado pela $\mathrm{OAB}$ e a despeito de todos os indicativos no sentido da manifesta inconstitucionalidade da Lei da Anistia e da impossibilidade de sua recepção no ordenamento jurídico brasileiro após a Constituição Federal de 1988.

\section{CONSIDERAÇÕES FINAIS}

Entrelaçar poder constituinte e justiça de transição é uma tarefa que pode ser realizada a partir de diferentes fundamentos. Procurou-se expor que as duas categorias, que possuem importância basilar na formação dos Estados Modernos, emanam alta voltagem política e jurídica. Logo, se o poder constituinte é aquele hábil a dispor limites capacitadores sobre os poderes de autogoverno da sociedade, a justiça de transição não pode ser afastada do mesmo, pois esta vai lidar com os procedimentos, julgamentos expurgos e reparações que se colocam como desafios para o novo regime político em relação ao anterior.

É possível identificar que um importante ponto comum entre os dois conceitos é a relação entre as diferentes gerações que operam os instrumentos institucionais disponibilizados. No caso do poder constituinte, os "fundadores" preocupam-se com as gerações futuras, a princípio, legando um aparato institucional que protege valores substantivos que entendem como os axiomas (premissas evidentes que são admitidas como universalmente válidas) ${ }^{4}$ daquela determinada comunidade. Enquanto que na justiça de transição, a geração superveniente precisa dispor de instrumentais para lidar com um passado que bloqueia a democracia, que reverbera nos órgãos administrativos e que deve ser submetido ao peculiar movimento de "desligamento", desaparelhamento, contudo, sem que isso implique em esquecimento, em uma auto-anistia, ou em um acordo político em condições profundamente díspares.

Por fim, é preciso observar que também o Direito se submete aos auspícios kairológicos. Conforme exposto, a política possui instantes de abertura, em que oportunidades, convergências, acordos são realizados e o momento instituinte

\footnotetext{
${ }^{4}$ Presentes, por exemplo na Declaração de Independência dos E.U.A.."Weholdthesetruthstobe selfevident $[\ldots] "$.
} 
pode ser perdido caso ela não venha a ser concretizada. Por isso, o mesmo fenômeno pode ser observado no campo do Direito. Se contemporaneamente a dicotomia forte entre Direito e Política não se sustenta em termos absolutos, mas, ao contrário, aponta-se para a conexão que gera tensões produtivas que podem ora privilegiar um ou outro, observa-se que o Direito também possui seus "instantes", seus momentos de abertura para o novo, momentos instituintes (que, eventualmente, podem caminhar pelas mesmas sendas que as decisões políticas) os quais precisam ser "agarrados",sob pena de um retorno a uma cronologia vazia e de baixa voltagem, em que a produção e a reprodução do direito se limitam a cumprir a função estabilizadora das relações sociais, não restando o Direito aberto para qualquer mudança proveniente do mundo da vida.

\section{REFERÊNCIAS}

ACKERMAN, Bruce. We the people. Cambridge: Harvard University, 1993.

ARENDT, Hannah. Sobre larevolución. Madrid: Alianza, 2009.

BARRY, Brian. Teorías de la justicia. Barcelona: Gedisa, 2001.

BRASIL. Constituição (1988). Constituição da República Federativa do Brasil. Disponível em: $<$ http://www.planalto.gov.br/ccivil_03/Constituicao/ Constituicao.htm>. Acesso em: 5 out. 2015.

BRASIL. Lei $\mathbf{n}^{\mathbf{0}} \mathbf{6 . 6 8 3}$, de 28 de agosto de 1979. Concede a anistia e dá outras providências. Disponível em: $<$ http://www.planalto.gov.br/ccivil_03/ leis/L6683.htm>. Acesso em: 5 out. 2015.

BRASIL. Lei $n^{0}$ 9.140, de 04 de dezembro de 1995. Reconhece como mortas pessoas desaparecidas em razão de participação, ou acusação de participação, em atividades políticas, no período de 2 de setembro de 1961 a 15 de agosto de 1979, e dá outras providências. Disponível em: $<$ http:// www.planalto.gov.br/ccivil_03/LEIS/L9140.htm>. Acesso em: 5 out. 2015.

BRASIL. Lei $\mathbf{n}^{\mathbf{0}}$ 9.882, de 3 de dezembro de 1999. Dispõe sobre o processo e julgamento da argüição de descumprimento de preceito 
fundamental, nos termos do $\S 1$ o do art. 102 da Constituição Federal. Disponível em: $<$ http://www.planalto.gov.br/ccivil_03/leis/19882.htm>.Acesso em: 5 out. 2015.

CLÉVE, Clèmerson Merlin. O direito e os direitos: elementos para uma crítica do direito contemporâneo. 3. ed. Belo Horizonte: Fórum, 2011.

CLÈVE, Clèmerson Merlin; DIAS, Cibele Fernandes. Algumas considerações em torno da argüição de descumprimento de preceito fundamental. In: SAMPAIO, José Adércio Leite. (Org.). Hermenêutica e jurisdição constitucional. Belo Horizonte: Del Rey, 2001.

DWORKIN, Ronald. O império do direito. São Paulo: Martins Fontes, 1999.

ELSTER, Jon. Closing the books: transitional justice in historical perspective. Cambridge: Cambridge University, 2004.

. Constitutional bootstrapping in philadelphia and Paris. In: ROSENFELD, Michel (Ed.). Constitutionalism, identity, difference, and legitimacy. Durham: Duke University, 1994.

. Ulysses and the sirens: studies in rationality and irrationality. Cambridge: Cambridge University, 1993.

. Ulysses unbound: studies in rationality, precommitment, and constraints. Cambridge: Cambridge University, 2000.

GARGARELLA, Roberto. Constitucionalismo versus democracia. In: GARGARELLA, Roberto. Teoría y crítica del derecho constitucional. Buenos Aires: Abeledo-Perrot, 2008.

JEFFERSON, Thomas. Escritos políticos. In: . Pensadores. São Paulo: Abril Cultural, 1973.

MÜLLER, Friedrich. Quem é o povo? a questão fundamental da democracia. São Paulo: Max Limonad, 1998. 
OST, François. O tempo do direito. Bauru: Edusc, 2005.

PILATTI, Adriano. A constituinte de 1987-1988: progressistas, conservadores, ordem econômica e regras do jogo. Rio de Janeiro: Lumen Juris, 2008.

ROCHA, Cármen Lúcia Antunes. Natureza e eficácia das disposições constitucionais transitórias. In: GRAU, Eros Roberto; GUERRA FILHO, Willis Santiago. Direito constitucional: estudos em homenagem a Paulo Bonavides. São Paulo: Malheiros, 2001.

SOUZA NETO, Cláudio Pereira de; SARMENTO, Daniel. Direito constitucional: teoria, história e métodos de trabalho. Belo Horizonte: Fórum, 2012.

Artigo recebido em: 22/09/2015 Aprovado para publicação em: 26/10/2015

Como citar: LORENZETTO, Bruno Menesses. KOZICKI, Katia. O Poder Constituinte e a Justiça de Transição no Brasil. Revista do Direito Público. Londrina, v.10, n.3, p.9-30, set/dez.2015. DOI: 10.5433/1980-511X.2015v10n3p9. ISSN: 1980-511X. 